\title{
Article \\ Impact of Herbicide Treatments on the Construction Materials in the Roman Wall of Lugo, Spain (UNESCO World Heritage Site)
}

\author{
Beatriz Prieto $^{1} \mathbb{D}$, Patricia Sanmartín ${ }^{1, * \mathbb{D}}$, Javier Cancelo-González ${ }^{1}$, Lucía Torres ${ }^{2,3}$ and Benita Silva ${ }^{1}$ \\ 1 Departamento de Edafoloxía e Química Agrícola, Facultade de Farmacia, Universidade de Santiago \\ de Compostela, 15782 Santiago de Compostela, Spain; beatriz.prieto@usc.es (B.P.); \\ javier.cancelo@usc.es (J.C.-G.); benita.silva@usc.es (B.S.) \\ 2 Departamento de Botánica, Escuela Politécnica Superior, Universidade de Santiago de Compostela, \\ 27002 Lugo, Spain; lu_to_ga@yahoo.es \\ 3 Departamento de Producción Vegetal y Proyectos de Ingeniería, Escuela Politécnica Superior, \\ Universidade de Santiago de Compostela, 27002 Lugo, Spain \\ * Correspondence: patricia.sanmartin@usc.es; Tel.: +34-881814984
}

Citation: Prieto, B.; Sanmartín, P.; Cancelo-González, J.; Torres, L.; Silva, B. Impact of Herbicide Treatments on the Construction Materials in the Roman Wall of Lugo, Spain (UNESCO World Heritage Site). Appl. Sci. 2021, 11, 5276. https://doi.org/ 10.3390/app11115276

Academic Editors: Maria

Filomena Macedo, António Manuel Santos Carriço Portugal, Ana Miller and Ana Catarina Pinheiro

Received: 28 April 2021

Accepted: 4 June 2021

Published: 7 June 2021

Publisher's Note: MDPI stays neutral with regard to jurisdictional claims in published maps and institutional affiliations.

Copyright: (c) 2021 by the authors. Licensee MDPI, Basel, Switzerland. This article is an open access article distributed under the terms and conditions of the Creative Commons Attribution (CC BY) license (https:/ / creativecommons.org/licenses/by/ $4.0 /)$.

\begin{abstract}
Combined laboratory and field research examining the possible alterations caused by herbicide treatments applied to the construction materials (schist and some granite, bound with mortar) in the Roman wall of Lugo (NW Spain), declared a World Heritage site by UNESCO in 2000, was performed in three separate studies in the past 20 years. In the summers of 1998 and 1999, the herbicides glyphosate, sulphosate and glufosinate-ammonium, as well as physical treatments (infrared and burning) were separately applied to different areas of the wall. In the spring of 2016, the oxyfluorfen herbicide Goal Supreme ${ }^{\circledR}$ was applied to test areas. In the winter of 2018, three essential oils, Origanum vulgare L., Thymus zygis Loefl. ex L., and Thymus vulgaris L., were each applied to test areas. Mineralogical modifications in the materials (determined by X-ray diffraction analysis), as well as visible physical changes, such as colour changes, and the appearance of saline residues were evaluated after the treatments. In the 1998/9 trial, glyphosate and both physical treatments triggered changes in the vermiculite clay minerals in the schists, and the physical treatments also caused changes in the kaolinite. None of the treatments caused highly perceptible colour changes. The oxyfluorfen herbicide did not cause any mineralogical alterations in the construction materials, but it did generate an increase in chloride, nitrate and sulphate contents of the granite and a slight darkening of this material. In the most recent study, the only deleterious effect observed was a perceptible increase in lightness and reduction in the yellow component after the application of Thymus zygis Loefl. ex L. essential oil to granite.
\end{abstract}

Keywords: built cultural heritage; cityscape; granite; laboratory and field analysis; maintenance plan; mortar; Parietaria judaica; schist; urban area; weed control

\section{Introduction}

The city of Lugo (Galicia, Northwest Spain) is renowned for its third century Roman wall (Figure 1). The wall represents one of the finest surviving examples of late Roman military fortifications and was declared a World Heritage site by UNESCO in 2000 (for further information, see references $[1,2])$. In relation to this recognition, efforts have been made in the last 20 years to conserve the construction materials (schist and to a lesser extent granite, bound together with mortar), which are subjected to strong biodeterioration phenomena caused by growth of biodeteriogenic vascular plant species [3]. Biodeterioration affects two-thirds of the world's historical buildings and stone monuments [4], with most of the studies focused on microphyte populations composed of cyanobacteria, algae and lichens (see [5,6], for recent reviews) and few focusing on the role of higher plants [4,7]. 

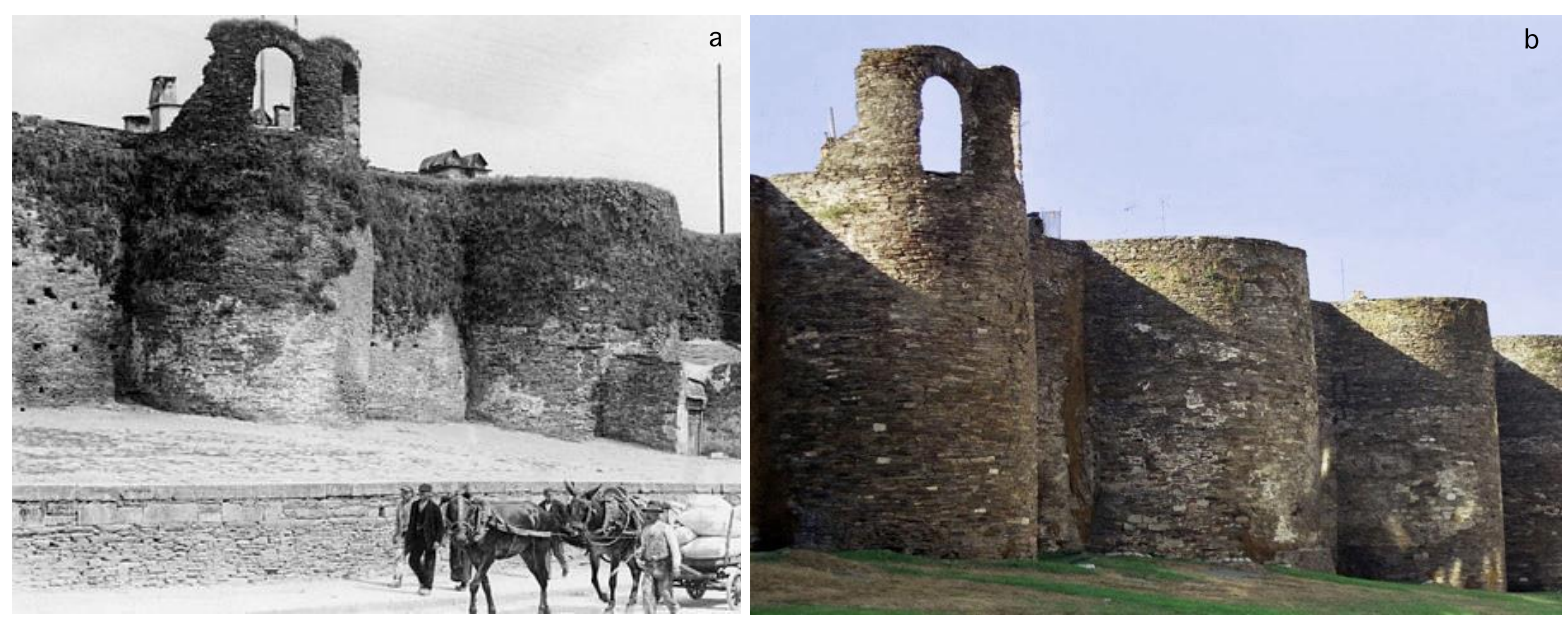

Figure 1. Images of the Roman wall of Lugo. (a) Photograph of the structure in 1928 (source: ABC, newspaper); (b) a recent photograph of the structure.

The propensity of a wall to provide a habitat for biological colonization, i.e., the bioreceptivity of the wall in a broad sense, considering intrinsic and extrinsic factors [8], mainly depends on its size, the construction materials, inclination, exposure and age [9]. The establishment of vascular plants generally requires crevices, fractures and interstices in the wall [10], and the heterogeneity of the building materials, exposure and slope are key factors at this stage [11]. Weed control in monumental walls is of particular importance, because plants can damage monuments with their roots, give the appearance of neglect, obstruct access to sites by visitors and/or conceal the monuments themselves [12]. On walls, the damage caused by root systems of herbaceous species, which tend to spread as pioneers, can have a significant influence on biodeterioration, causing cracking, deformation and detachment [13-15]. In the Roman wall of Lugo, the weeds are removed annually, and herbicide treatments are injected in the roots and stems of vascular plants or by spraying to prevent mechanical damage to the stone. The breakage and loss of cohesion of the structure, rather than aesthetic factors (about which opinions may differ), lead to systematic treatments being applied to weeds on the wall every year.

Mowing and clearing procedures such as cutting are commonly used for weed control. However, these may be insufficient because perennial vegetation rapidly reinfests the same sites because their roots remain alive and regenerate as soon as the climatic and substratum conditions are favourable [16]. This leads to the use of herbicides, among which, nitro-organic compounds (amides, diazines, triazines, piridines and urea derivates) and organophosphorous compounds have been the most commonly used [17], up until the time the present study was carried out. The ideal characteristics of herbicides include low toxicity, low risk of environmental pollution, high efficacy against biodeteriogens, wide range of action, easy to use, no interference with the substratum and low cost [18,19]. In this respect, a low usable dose of herbicide, which can be encouraged by the method of application (for instance, injection in roots instead of spraying), generally entails an actual decrease in the risk to human health and the environment, along with less interference with the substrate [17].

Herbicides can be divided into two broad categories: contact herbicides and systemic herbicides. The former act in the proximity of the areas of entry, while the latter (which are the most commonly used) act after penetration and are transported to other parts of the plant where they act [17]. Historically, glyphosate-based herbicides have been widely used for weed control [17]. In the Roman wall of Lugo, in the late 1990s, chemical herbicides, such as glyphosate, were applied prior to further clearing by manual mowing. Changes in regulations and public health policies regarding the use of glyphosate-based herbicides in urban areas, after the reclassification of glyphosate as a Category 2A compound (probably carcinogenic to humans) by the International Agency for Research on Cancer (IARC) in 
2015 , led to the search for green conservation strategies. Thus, oxyfluorfen was tested in 2016 and three formulations composed of Origanum and Thymus spp. essential oils were tested in 2018.

The Roman wall of Lugo fosters a varied biological colonization, including vascular flora (with Parietaria judaica or pellitory-of-the-wall currently dominating), mainly on the mortar that binds the ancient stones and the soil and other particles that accumulate on the ledges [3]. Parietaria judaica, which is often found in shaded and nitrate-rich microhabitats, such as in rock environments close to bird nests [20], is abundant on the mortar, which is then loosened through the transfer of moisture to the plants [21].

Possible interference with materials has rarely been considered, and few studies, mainly conducted in North America and Italy in the 1990s, reported results of preserving historical stone and masonry by weed control [22-27]. In the present study, which forms part of a wider research project on the best practices for controlling the flora on the Roman wall of Lugo (NW Spain), as well as the assessment of the impact of treatment on Parietaria judaica and the analysis of the run-off water from the wall [3], the potential impacts of the treatments on the construction materials of the wall were examined in field and laboratory tests. Samples of schist and mortar (mainly from the wall) were characterized in detail and the impacts on all materials (schist, mortar and granite), considering colour changes, the appearance of saline residues and mineralogical alterations after the herbicidal treatments used in the last 20 years, are reported.

\section{Materials and Methods}

\subsection{Case Study}

The Roman wall of Lugo, built between 263 and 276 A.D. to defend the Roman town of Lucus Augusti (nowadays Lugo, Figure 2a) against local tribesmen and Germanic invaders, is particularly well preserved, and the entire perimeter remains intact (Figure 2b).

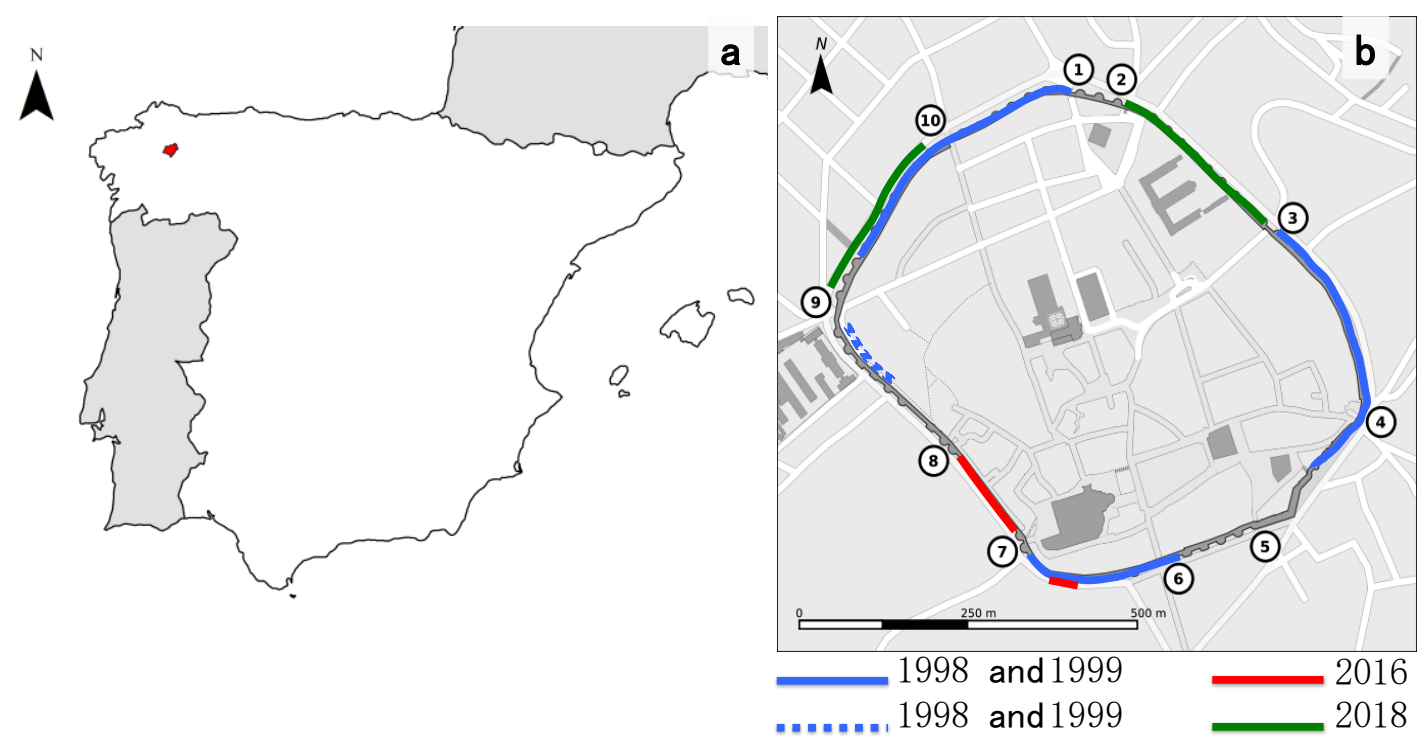

Figure 2. (a) ArcGIS Map of the Iberian Peninsula showing the location of the city of Lugo (red area); (b) map of the Roman wall of Lugo, showing the test areas of the wall (solid and dashed lines represent, respectively, internal and external faces of the wall) where the treatments were applied over time, and the entrance gates (1: San Fernando Gate, 2: False Gate, 3: Station Gate, 4: San Pedro Gate, 5: Bishop Izquierdo Gate, 6: Bishop Aguirre Gate, 7: Santiago Gate or Pexigo Gate, 8: Gate of El Carmen or Miñá Gate, 9: Bishop Odoario Gate, 10: New Gate).

The wall is around $2120 \mathrm{~m}(6960 \mathrm{ft})$ long, encloses an area of $34.4 \mathrm{ha}$, is about $4.2 \mathrm{~m}$ $(14 \mathrm{ft})$ wide and varies in height between $8 \mathrm{~m}(26 \mathrm{ft})$ and $12 \mathrm{~m}(39 \mathrm{ft})$. The wall consists of internal and external stone faces with a core of earth mixed with gravel, pebbles and worked Roman stone recycled from demolished buildings, cemented with water. The 
walled enclosure is accessed through 10 gates (Figure 2b), of which five date to Roman times (False Gate [2] and Miñá Gate [8] are the best preserved) and five were added after 1853 in response to urban growth.

At present, the dominant species on the Roman wall is Parietaria judaica, followed by Cymbalaria muralis, with a more seasonal character and offering fewer problems in its control. In the successive inventories carried out during the last decade, the presence of other less representative species belonging to the genera Andryala, Epilobium, Oxalis, Soleirolia, Sonchus, Umbilicus and Vulpia have been detected on the wall.

\subsection{Characterization of the Construction Materials}

The construction materials of the Roman wall of Lugo mainly consist of schist (affected by different degrees of weathering) and to a lesser extent granite, bound together with mortar.

Representative samples of schist were visually classified in 3 categories: weakly weathered, moderately weathered and strongly weathered. Three samples from each of the three categories were characterized petrographically and mineralogically by thin-section analysis (by examination under a light optical microscope) and by X-ray diffraction (XRD) analysis. Powdered samples of particles with sizes less than $50 \mu \mathrm{m}$ were studied with a PW1710 Philips diffractometer (Amsterdam, the Netherlands) equipped with a PW 1820/00 goniometer and an Enraf Nonius FR590 generator operating at $40 \mathrm{kV}$ and $30 \mathrm{~mA}$. The X-rays were obtained with $\mathrm{CuK} \alpha$-radiation $(\lambda=1.5406 \AA)$, and the XRD diffractogram patterns were acquired in the angular range of $2<2 \theta<65$ with a step size of $0.02^{\circ}$ and a measuring time of $2 \mathrm{~s}$ per step. The minerals were identified by comparison with the ICSD and COD databases.

Ten mortar samples taken from both inner and outer faces of the wall (five samples of each) were characterized by X-ray diffraction analysis, as previously described for schist samples. The moisture content (expressed as a percentage) of the mortar samples under natural conditions was calculated relative to the dry weight at $110^{\circ} \mathrm{C}$. The aggregate and binder were separated by gradual heating of the samples to a maximum temperature of $550{ }^{\circ} \mathrm{C}$ for the time required to achieve total deagglomeration, and the aggregate/binder ratios were determined by gravimetry. The nature and particle size distributions of the aggregates were also determined. Note that these samples do not correspond to original Roman work but to recent interventions. Deeper samples were not obtained, as the objective of the study was to determine the effect of the treatments on the exposed masonry material.

\subsection{Experimental Field and Laboratory Trials with Herbicide Treatments}

Laboratory- and field-based research trials were carried out in 1998 and 1999, 2016 and 2018 on different areas of the wall, to assess the possible alterations caused by herbicidal treatments applied to the construction materials in the Roman wall of Lugo (Table 1), within a wider project on the implementation of best practices for controlling flora. The main problems caused by the use of herbicides on cultural heritage asset are (1) negative side effects on the substrate and (2) hazards to the operator [28]. Regarding the former, the main problems that may arise are colour modifications, the appearance of saline residues and mineralogical alterations in stone materials, which are those aspects analysed in the present study. Mineralogical (X-ray diffraction analysis) and chemical (appearance of saline residues) modifications in the materials were evaluated after the application of each herbicidal treatment directly on the wall. Otherwise, physical change (colour change) was evaluated after the application of herbicidal treatments on samples in the laboratory.

\subsubsection{Herbicidal Application and Sampling}

Different herbicide treatments (Table 1) were used in each trial following changes in regulations and public health policies. Treatments acting on developed plants were applied in spring or summer, while those acting on germination were applied in winter. 
In order to ensure that the various treatments were not applied to the same material, different parts of the wall were selected for each trial and treatment. This fact, together with the difficulties inherent in sampling monuments, led to differences in the type and number of samples and the time during which monitoring was conducted, as different types of permission had to be obtained for each trial.

Table 1. Summary of the experimental field and laboratory trials with herbicide treatments.

\begin{tabular}{|c|c|c|c|c|}
\hline Trial Date & Treatment & Preparation & $\begin{array}{l}\text { Application in the } \\
\text { Field }\end{array}$ & $\begin{array}{l}\text { Application in the } \\
\text { Laboratory }\end{array}$ \\
\hline \multirow[b]{2}{*}{$\begin{array}{l}\text { Summer } 1998 \text { and } \\
\text { summer } 1999\end{array}$} & $\begin{array}{l}\text { Infrared treatment }(\mathrm{I})^{(1)} \\
\text { Burn treatment }(\mathrm{B})^{(1)}\end{array}$ & Not applicable & $\begin{array}{l}\text { At } 2.5-3.5 \text { bar pressure } \\
\text { Application time: } 10 \\
\text { min (I) and } 1-2 \min (B)\end{array}$ & Not applicable \\
\hline & $\begin{array}{l}\text { Glyphosate (G) } \\
\text { Sulphosate (S) } \\
\text { Glufosinate-- } \\
\text { ammonium (G-a) }\end{array}$ & $\begin{array}{c}\text { For each chemical, an } \\
\text { aqueous solution at } 2.5 \% \\
v / v \text { plus the wetting agent } \\
\text { nonylphenyl polyethylene } \\
\text { glycol at } 0.15 \% v / v\end{array}$ & $\begin{array}{r}20 \mathrm{~mL} / \mathrm{m}^{2}(\mathrm{G} \text { and } \mathrm{S}) \\
\text { and } 30 \mathrm{~mL} / \mathrm{m}^{2}(\mathrm{G}-\mathrm{a}) \\
\text { with a low volume } \\
\text { hand-held sprayer }\end{array}$ & 1-h immersion ${ }^{(2)}$ \\
\hline Spring 2016 & Oxyfluorfen & $\begin{array}{l}\text { Aqueous solution at } 0.5 \% \\
v / v, 1.25 \% v / v, 100 \% v / v\end{array}$ & $\begin{array}{c}20 \mathrm{~mL} / \mathrm{m}^{2} \text { of solution } \\
\text { at } 1.25 \% \text { v/v with an } \\
\text { ultra-low volume } \\
\text { sprayer }^{(3)}\end{array}$ & $\begin{array}{c}\text { Solutions at } 0.5 \% v / v, \\
1.25 \% \text { v } v^{(3)} \text { and } 100 \% \\
v / v \text { applied by brush }\end{array}$ \\
\hline Winter 2018 & $\begin{array}{l}\text { Origanum vulgare L. } \\
\text { Thymus zygis Loefl. ex } \\
\text { L. Thymus vulgaris L. }\end{array}$ & $\begin{array}{c}\text { Aqueous solution at } 2 \% v / v \\
\text { plus the herbicide adjuvant } \\
\text { Oil Oro at } 2 \% v / v\end{array}$ & $\begin{array}{l}250 \mathrm{~mL} / \mathrm{m}^{2} \text { with an } \\
\text { ultra-low volume } \\
\text { sprayer }^{(3)}\end{array}$ & By brush ${ }^{(3)}$ \\
\hline
\end{tabular}

${ }^{(1)}$ Not applied in 1999. ${ }^{(2)}$ Applied in 1999. (3) Two applications.

\subsubsection{Trials Performed in 1998 and 1999}

Two physical treatments, i.e., infrared and burning, and three chemical treatments, i.e., glyphosate (trade name: Roundup Ultra Plus, isopropylamine salt $36 \% w / v$, Monsanto, Creve Coeur, MO, USA), sulphosate (trade name: Touchdown, trimethyl-salt with N-(phosphonomethyl)glycine 48\% w/v, Syngenta Agro, Switzerland) and glufosinateammonium (trade name: Finale, glufosinate-ammonium 15\% w/v, Bayer, Crop Science, Germany), each applied at $2.5 \% v / v$, together with a wetting agent (nonylphenyl polyethylene glycol solution 20\% w/v, Sigma-Aldrich, St. Louis, MO, USA, at $0.15 \% v / v$ ) were tested in the first trial. Each treatment (Table 1) was applied to three test areas $(1.5 \mathrm{~m} \times 2.5 \mathrm{~m})$ in the outer face of the wall (15 test areas) and in the inner face of the wall (15 test areas), in the summer of 1998 (Figure 2b). One year later, in the summer of 1999, chemical treatments were again applied in the same test areas. Physical treatments were not repeated, as they gave rise to alterations in the materials (see result section). All test areas included schist with the three different degrees of weathering indicated in Section 2.2, mortar and scarce granite. There was no granite in those test areas where physical treatments were applied.

In order to analyse possible modifications to materials due to herbicidal treatments, one piece of each type of masonry material (granite and weakly, moderately and strongly weathered schist) and one piece of mortar were selected in each test area. A portion of these pieces of approximately $8 \mathrm{~cm}^{3}$ was obtained at different times: 17 days before and one year after the treatments, i.e., just before the re-application of chemical treatments (summer 1999). Five weeks after re-application, portions from the same pieces were collected.

In addition, two representative, untreated pieces of schist masonry differing in colour and texture and two representative, untreated pieces of granite masonry, each of about $40 \mathrm{~cm}^{3}$ and differing in colour and texture, were taken from the wall. Each piece was divided into three portions, and glyphosate, sulphosate and glufosinate-ammonium (the three chemical treatments) were applied (Table 1) in order to analyse surface colour modifications three months after the application. 


\subsubsection{Trials Performed in 2016}

In the spring of 2016, oxyfluorfen (trade name: Goal Supreme, 2-chloro-1-(3-ethoxy4-nitrophenoxy)-4-(trifluoromethyl) benzene $48 \% w / v$, Dow AgroSciences, Indianapolis, IN, USA) was applied twice at a concentration of $1.25 \% v / v$ to three test areas $\left(70-200 \mathrm{~m}^{2}\right)$ in the outer face of the wall (Figure 2b, Table 1). Before the application of the oxyfluorfen herbicide, one piece of schist masonry, granite masonry and mortar were selected in each test area and a portion of these pieces, of approximately $8 \mathrm{~cm}^{3}$, was obtained immediately before and six months after the application of the herbicide.

Moreover, three pieces of untreated schist masonry and one piece of untreated granite masonry (present in a low proportion in the wall) were removed for treatment in the laboratory and analysis of the change in colour induced three months after the application. Each piece of approximately $40 \mathrm{~cm}^{3}$ was divided in three portions and the oxyfluorfen herbicide was applied, as follows: (1) twice at $1.25 \% v / v$ to simulate the treatment carried out on the wall to three portion samples of granite and schist, (2) at $0.5 \% v / v$ to represent a low level of application to three portion samples of schist, and (3) at 100\% v/v to represent the maximum effect that the herbicide could cause, if, e.g., the product was spilled on the materials by accident, to three portion samples of schist.

\subsubsection{Trials Performed in 2018}

In winter 2018, Origanum vulgare L., Thymus zygis Loefl. ex L., and Thymus vulgaris L. essential oils (for chemical composition, see Table 2) were each applied at $2 \% v / v$, together with herbicide adjuvant marketed under the trade name Oil Oro (paraffinic oil surfactant blend/emulsifier at $83 \%$, Químicas Oro, Spain) at $2 \% v / v$, to the outer part of the wall (Figure 2b, Table 1).

Table 2. Chemical composition of the three essential oils determined by gas chromatography, with detection by mass spectrometry (GC/MS), flame ionization detection (GC/FID), or proton nuclear magnetic resonance (NMR) of the oils in deuterated chloroform. Data provided by the producer (Esencias Martínez Lozano, Murcia, Spain).

\begin{tabular}{|c|c|c|c|}
\hline Compound $^{(1)}$ & Origanum vulgare $\mathrm{L}$. & Thymus zygis Loefl. ex L. & Thymus vulgaris $\mathrm{L}$. \\
\hline$\alpha$-pinene & $0.91^{(2)}$ & $1.26^{(2)}$ & - \\
\hline$\alpha$-thuyene & 1.05 & 0.73 & - \\
\hline$\beta$-myrcene & 1.50 & 1.62 & $3.50^{(3)}$ \\
\hline$\alpha$-terpinene & 1.12 & 1,45 & 8.14 \\
\hline p-cymene & 6.34 & 19.23 & 2.68 \\
\hline limonene & - & - & 3.01 \\
\hline 1-8-cineole & - & - & 1.30 \\
\hline$\gamma$-terpinene & 4.66 & 8.06 & - \\
\hline linalool & 1.30 & 4,71 & 81.37 \\
\hline camphor & - & 0.79 & - \\
\hline borneol & - & 1.30 & - \\
\hline 4-terpineol & 0.78 & 1.04 & - \\
\hline thymol & 3.80 & 49.39 & - \\
\hline carvacrol & 70.24 & 2.76 & - \\
\hline $\begin{array}{c}\beta- \\
\text { caryophyllene }\end{array}$ & 2.23 & 1.48 & - \\
\hline
\end{tabular}

(1) Compounds detected by mass spectrometry analysis and retention times (in percentage $\geq 0.5 \%$ ), or proton nuclear magnetic resonance (NMR). ${ }^{(2)}$ Percentages calculated from GC/FID without correction factor. ${ }^{(3)}$ Percentages relative to the total of the compounds detected by NMR. The spectra obtained were compared with those of the pure compounds obtained from the Sigma-Aldrich website (https: / / www.sigmaaldrich.com (accessed on 5 June 2021)), the "Spectral Database for Organic Compounds, SDBS" and the base SciFinder.

Each treatment was applied (Table 1) to two test areas of $9 \mathrm{~m}^{2}(1.2 \mathrm{~m} \times 7.5 \mathrm{~m})$. In each test area, two pieces each of schist masonry and granite masonry were obtained (four masonry pieces of each material); a sample of these pieces of about $8 \mathrm{~cm}^{3}$ was taken 
immediately before and 3 months after treatment in order to analyse mineralogical and chemically induced modifications.

In addition, three untreated granite masonry pieces and three untreated schist masonry pieces, each of about $40 \mathrm{~cm}^{3}$, were taken from the wall. Each piece was divided in three portions and Origanum vulgare L., Thymus zygis Loefl. ex L., and Thymus vulgaris L. essential oils were applied (Table 1) to test any colour change, determined in the laboratory three months after the application.

\subsubsection{Analysis of Interactions between the Herbicidal Treatments and the Substrate}

The mineralogy of the samples before and after the interventions on the wall was determined by X-ray diffraction (XRD) analysis, with the same device and conditions described in Section 2.2.

In order to analyse the presence of soluble salts due to herbicidal treatments, the ion content $\left(\mathrm{Cl}^{-}, \mathrm{NO}_{3}{ }^{-}, \mathrm{SO}_{4}{ }^{-2}, \mathrm{HCO}_{3}{ }^{-}\right.$and $\left.\mathrm{PO}_{4}{ }^{-3}\right)$ and cation content $\left(\mathrm{NH}_{4}{ }^{+}\right.$, only in the first trial) were measured in samples of the wall taken before and after the application of the herbicide. The soluble salts were extracted during $24 \mathrm{~h}$ from $1 \mathrm{~g}$ of sample ground to a particle size of less than $4 \mathrm{~mm}$ with $10 \mathrm{~mL}$ of ultrapure water. The extracts were filtered $(0.45 \mu \mathrm{m})$ and the ions present were analysed. The chloride $\left(\mathrm{mg} \mathrm{Cl}^{-} / \mathrm{g}\right)$, nitrate $(\mathrm{mg}$ $\left.\mathrm{NO}_{3}{ }^{-} / \mathrm{g}\right)$, sulphate $\left(\mathrm{mg} \mathrm{SO}_{4}{ }^{-2} / \mathrm{g}\right)$ and phosphate $\left(\mathrm{mg} \mathrm{PO}_{4}^{-3} / \mathrm{g}\right)$ contents were determined in a 930 Compact IC Flex (Metrohm, Switzerland) ion chromatography system. The ammonium ion content $\left(\mathrm{mg} \mathrm{NH}_{4}{ }^{+} / \mathrm{g}\right.$ ) was determined with a selective ORION 720 electrode. The bicarbonate content ( $\mathrm{mg} \mathrm{HCO}_{3}{ }^{-} / \mathrm{g}$ ) was analysed by potentiometric titration (Compact titrometer, Crison, Barcelona, Spain).

The colour change was recorded immediately before and three months after herbicide application, with a Konica Minolta tristimulus colourimeter equipped with a CR-300 measuring head (1998 and 1999) or with a portable spectrophotometer (Konica Minolta CM-700d) equipped with CMS100w (SpectraMagicTM NX) software (2016 and 2018). The measurement conditions in both devices were illuminant D65, observer $2^{\circ}$ and target area, 8 -mm diameter. A number of readings (in proportion to the size of sample) were made at different randomly selected zones on each sample [29]. The measurements were made in the CIELAB colour space [30] and expressed as $\mathrm{L}^{*}, \mathrm{a}^{*}$, and $\mathrm{b}^{*}$. Partial colour differences $\left(\Delta \mathrm{L}^{*}, \Delta \mathrm{a}^{*}\right.$, and $\left.\Delta \mathrm{b}^{*}\right)$, i.e., before and after treatment, represent the change in lightness $\left(\Delta \mathrm{L}^{*}\right)$, from black (negative value) to white (positive value), the change in the green-red component $\left(\Delta \mathrm{a}^{*}\right)$, from greenness (negative value) to redness (positive value), and the change in the blue-yellow component $\left(\Delta \mathrm{b}^{*}\right)$, from blueness (negative value) to yellowness (positive value). The total or global colour difference $\left(\Delta \mathrm{E}_{\mathrm{ab}}^{*}\right)$ was determined according to UNE-EN 15886 [31] by using the following equation:

$$
\Delta \mathrm{E}^{*}{ }_{\mathrm{ab}}=\left(\Delta \mathrm{L}^{* 2}+\Delta \mathrm{a}^{* 2}+\Delta \mathrm{b}^{* 2}\right)^{1 / 2},
$$

To determine any perceptible colour changes in these three colour attributes and in the global colour, a threshold of 3 CIELAB units was assumed to indicate a notable change in colour [32-34].

\section{Results}

\subsection{Characterization of Construction Materials}

The three schist samples (weakly, moderately and strongly weathered) can be described as micaceous quartz schist with marked foliation, composed of micaceous minerals (biotite, muscovite and chlorite), quartz and accessory minerals (Figure 3, Table 3). 

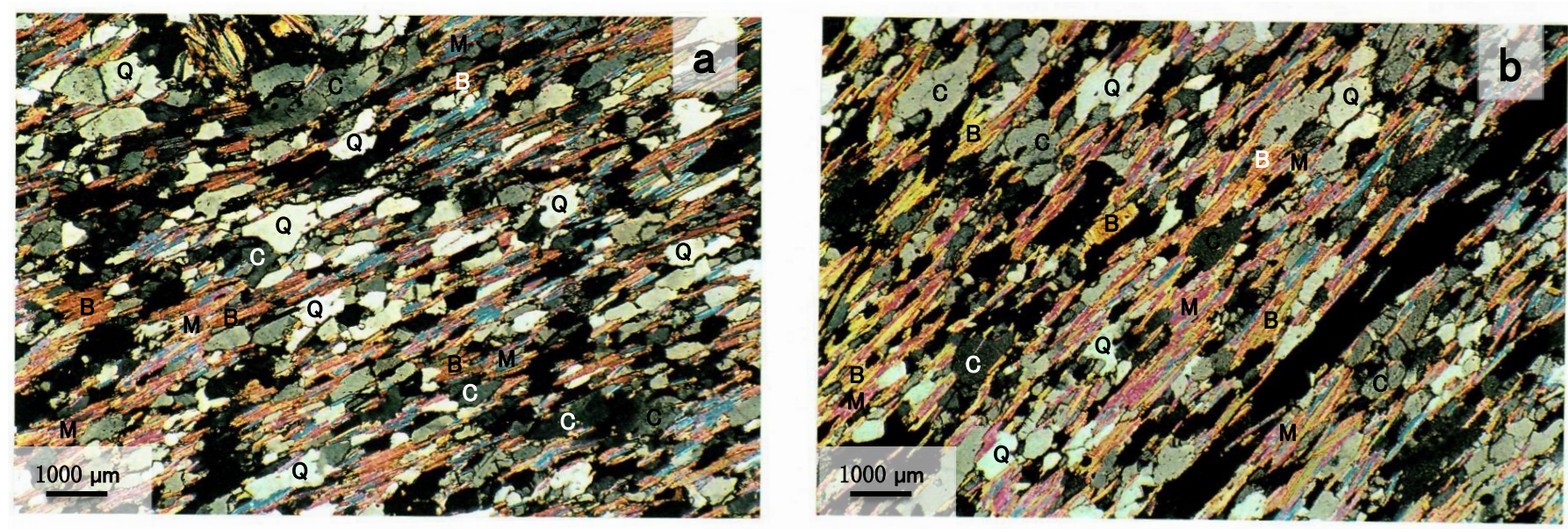

Figure 3. Thin sections of the weakly (a) and strongly (b) weathered schist samples. ' $Q$ ', ' $C$ ', ' $B$ ', and 'M' denote the quartz, chlorite, biotite and muscovite grains, respectively, and the pores and foliation appear in black.

Table 3. Mineral composition of the schist by modal analysis. The values are expressed as mean \pm error (in percentage) of three independent thin sections from three subsamples from each category.

\begin{tabular}{cccc}
\hline \multirow{2}{*}{ Mineral } & \multicolumn{3}{c}{ Degree of Weathering of Schist } \\
\cline { 2 - 4 } & Weak & Moderate & Strong \\
\hline Quartz & $31.6 \pm 4.1$ & $37.0 \pm 2.8$ & $30.3 \pm 5.0$ \\
Biotite & $19.7 \pm 2.8$ & $26.1 \pm 2.4$ & $37.9 \pm 3.6$ \\
Muscovite & $28.9 \pm 2.2$ & $17.4 \pm 1.8$ & $18.2 \pm 1.5$ \\
Chlorite & $14.5 \pm 1.1$ & $13.0 \pm 1.0$ & $10.6 \pm 0.9$ \\
Accessory minerals & $5.3 \pm 0.3$ & $6.5 \pm 0.6$ & $3.0 \pm 0.7$ \\
\hline
\end{tabular}

Thin-section analysis of the weakly weathered schist showed that the biotite was formed by crystals of a tabular-laminar habit $(0.1-0.8 \mathrm{~mm})$ with brown-yellow pleochroism and frequent pleochroic halos; no alteration processes were observed (Figure 3a). Muscovite, with crystals of 0.06 to $0.15 \mathrm{~mm}$, was interwoven with biotite. Isolated chlorite crystals $(0.10-0.45 \mathrm{~mm})$ were scarce; however, chlorite blasts $(1.2 \times 0.7 \mathrm{~mm})-(1.6 \times 1.0 \mathrm{~mm})$ were frequent, constituted in turn by aggregates of chlorite crystals, quartz crystals, biotites and some iron ore. Quartz occurred in allotriomorphic crystals that tended to be elongated and occupied the intercrystalline positions of micas. These crystals varied in size from 0.05 to $0.25 \mathrm{~mm}$, although larger crystals were also observed $(0.5 \times 0.10 \mathrm{~mm})$. Accessory minerals were frequent, particularly apatite in rounded and elongated crystals $(0.05-0.15 \mathrm{~mm})$, zircon in small, rounded crystals $(0.03 \mathrm{~mm})$ as inclusion in biotite, opaque iron minerals in small sections of sizes from $0.05-0.01 \mathrm{~mm}$ and feldspars forming part of the chlorite blasts.

Thin-section analysis of the moderately weathered schist showed that the biotite was formed by crystals of a tabular-laminar habit $(0.10-0.25 \mathrm{~mm})$ with distinct pleochroism (from brown-yellow to white) bordering the quartz crystals. No obvious alteration processes were observed in biotite crystals. Muscovite occurred in colourless tabular crystals associated with biotite. The crystals varied in size from 0.12 to $0.20 \mathrm{~mm}$. Chlorite appeared in tabular crystals ranging from $0.12 \mathrm{~mm}$ to $0.25 \mathrm{~mm}$, forming aggregates of chlorites or chlorite blasts (of sizes from $1.0 \times 0.9 \mathrm{~mm}-2.4 \times 1.6 \mathrm{~mm}$ ) made up of aggregates of chlorite and quartz crystals. Rock foliation tended to deform around the grains. The following accessory minerals, which were relatively frequent and represent a source of metamorphic granitic-pegmatitic materials, were detected: apatite, in rounded and elongated crystals $(0.08-0.15 \mathrm{~mm})$; tourmaline, in sub-rounded crystals $(0.05-0.15 \mathrm{~mm})$; zircon, in small, rounded crystals $(0.03-0.05 \mathrm{~mm})$; iron minerals, in small sections $(0.02-0.08 \mathrm{~mm})$; and, feldspars forming part of the chlorite blasts. 
Thin-section analysis of the strongly weathered schist (Figure 3b) showed that the biotite was formed by crystals of a tabular-laminar habit $(0.12-0.5 \mathrm{~mm})$ with brownyellow pleochroism; no alteration processes were observed, only the slight segregation of iron oxyhydroxides. Muscovite crystals of 0.10 to $0.20 \mathrm{~mm}$ were interwoven with biotite. Chlorite appeared as well-developed tabular crystals $(0.15-0.40 \mathrm{~mm})$ generally oriented transversely to the foliation. Although present in isolated cysts, chlorite usually occurred as aggregates or blasts $(1.25 \times 0.30 \mathrm{~mm})$, formed in turn by aggregates of crystals and some degree of laminar development. Quartz occurred in allotriomorphic crystals occupying the intercrystalline positions of micas. The quartz crystals varied in size from $0.07 \mathrm{~mm}$ to $0.50 \mathrm{~mm}$. Although the crystals were allotriomorphic, elongated sections oriented according to the foliation predominated. As accessory minerals, small opaque iron oxide crystals $(0.05-0.10 \mathrm{~mm})$ predominated in individual sections, and some iron hydroxides scattered in the micaceous matrix gave the sample an overall reddish-brown colour. Some feldspar crystals were also observed forming part of the chlorite blasts.

The schist samples analysed are therefore almost identical in mineralogical composition and structure. They probably correspond to the Precambrian schist formation of Villalba [35], a small town near the city of Lugo. The samples are formed by weakly weathered minerals, such as quartz and muscovite (Table 3), only containing biotite as an easily weathered component. Biotite determines the degree of weathering in the different samples, as indicated by the iron oxyhydroxides secreted, which give the most altered rock samples a browner colour, and by the greater porosity, with holes of a planar type, i.e., fissures that follow the direction of foliation of the rock samples (Figure 3b).

In addition to these results, $\mathrm{X}$-ray diffraction analysis showed that some of the micaceous minerals are interstratified, i.e., mica-chlorite, mica-vermiculite, and vermiculitechlorite. This is an interesting finding because it is precisely the interstratified minerals which may be most susceptible to being modified by the treatments.

Regarding the mortar samples, calcite $\left(\mathrm{CaCO}_{3}\right)$ and crushed quarry material containing quartz, feldspar and mica minerals (from granite) and chlorite (from schist) were identified in all samples, confirming that the mortars are lime-based. Some samples also contained large amounts of kaolinite, indicating a fine inert charge such as mud or clay, common in old mortars. Furthermore, the samples were quite coherent, which indicates the complete carbonation of the lime (calcium oxide, $\mathrm{CaO}$ ). Under natural conditions, the moisture content, which varies between $0.7 \%$ and $1.90 \%$, is not related to the position of the mortar in the outer or in the inner part of the wall (Table 4). In general, except for sample 6I, the mortars contain very little binder, especially those from the outer face, where the percentage of binder varied between $6.36 \%$ and $11.47 \%$. Mortars from the inner face contained larger amounts of binder, between $10.13 \%$ and $21.24 \%$. The difference between mortar samples from both faces of the wall was also observed in the particle size distribution of the aggregates (Table 4).

Table 4. Moisture content, particle size distribution of the aggregates and aggregate/binder ratio of the mortar samples.

\begin{tabular}{|c|c|c|c|c|c|c|c|c|c|}
\hline \multirow{2}{*}{ Sample ${ }^{(1)}$} & \multirow{2}{*}{$\mathbf{M}^{(2)}$} & \multicolumn{6}{|c|}{ Aggregate (3) } & \multirow{2}{*}{ Binder $^{(3)}$} & \multirow{2}{*}{$\begin{array}{c}\text { Aggregate/ } \\
\text { Binder Ratio }\end{array}$} \\
\hline & & $>4 \mathrm{~mm}$ & 4-2 mm & 2-1 mm & $1-0.5 \mathrm{~mm}$ & $0.5-0.25 \mathrm{~mm}$ & $0.25-0.10 \mathrm{~mm}$ & & \\
\hline 10 & 1.40 & 0.00 & 15.50 & 31.60 & 26.90 & 15.58 & 10.42 & 11.47 & 7.72 \\
\hline $2 \mathrm{O}$ & 0.70 & 8.39 & 23.35 & 37.66 & 18.94 & 6.39 & 5.27 & 8.75 & 10.42 \\
\hline 30 & 1.68 & 5.06 & 16.06 & 32.68 & 31.74 & 9.35 & 5.12 & 8.34 & 10.99 \\
\hline 40 & 1.63 & 3.47 & 20.85 & 34.26 & 30.13 & 7.36 & 3.93 & 6.36 & 14.72 \\
\hline 50 & 1.66 & 7.25 & 19.72 & 31.94 & 28.21 & 7.88 & 4.99 & 8.18 & 11.22 \\
\hline $6 \mathrm{I}$ & 1.90 & 0.88 & 14.93 & 26.95 & 25.91 & 18.52 & 12.81 & 21.24 & 3.70 \\
\hline 7I & 0.96 & 7.24 & 36.14 & 23.47 & 16.11 & 9.49 & 7.55 & 10.13 & 8.87 \\
\hline $8 \mathrm{I}$ & 1.05 & 8.10 & 25.44 & 24.14 & 19.96 & 12.71 & 9.66 & 11.73 & 7.52 \\
\hline 9I & 1.65 & 1.30 & 21.82 & 26.87 & 22.78 & 17.11 & 10.11 & 14.65 & 5.82 \\
\hline 10I & 1.37 & 0.00 & 17.17 & 28.47 & 23.51 & 17.87 & 12.98 & 16.45 & 5.08 \\
\hline
\end{tabular}

(1) O: from the outer face of the wall. I: from the inner face of the wall. ${ }^{(2)} \mathrm{M}$ : moisture content (in percentage). ${ }^{(3)}$ Percentage. 


\subsection{Impact of Herbicide Treatment on the Construction Materials}

In the first trial (1998 and 1999), of the three chemical treatments tested, only glyphosate caused detectable mineralogical alteration of the schist samples, triggering the disappearance of vermiculite (Table 5), as the signal disappeared at $1.4 \mathrm{~mm}$ in the $X$-ray diffractograms at the same time as the signal increased by around $1.0 \mathrm{~mm}$. Glyphosate can cause the complexation of iron and aluminum, both of which are present in vermiculite; if this occurs, it would be detected by a change in the interlaminar spacing of the vermiculite, which would shift from $1.4 \mathrm{~mm}$ to around $1.0 \mathrm{~mm}$, overlapping with the signal of biotite and muscovite. No mineralogical changes were detected in granite after the application of the chemicals.

Table 5. Changes in the ion content and the mineral composition. +: change detected; -: no change detected; n.c.: not considered; d.k.: disappearance of kaolinite; d.v.: disappearance of vermiculite.

\begin{tabular}{|c|c|c|c|c|c|c|c|c|c|c|}
\hline & & $\mathbf{I}$ & B & G & $\mathrm{S}$ & G-a & $\mathbf{O}$ & O. $v$. & T. $z$. & T. $v$. \\
\hline \multirow{3}{*}{$\mathrm{Cl}^{-}$} & Schist & n.c. & n.c. & - & - & - & + & - & - & - \\
\hline & Granite & n.c. & n.c. & - & - & - & + & - & - & - \\
\hline & Mortar & n.c. & n.c. & - & - & - & + & - & - & - \\
\hline \multirow{3}{*}{$\mathrm{NO}_{3}{ }^{-}$} & Schist & n.c. & n.c. & - & - & - & + & - & - & - \\
\hline & Granite & n.c. & n.c. & - & - & - & + & - & - & - \\
\hline & Mortar & n.c. & n.c. & - & - & - & + & - & - & - \\
\hline \multirow{3}{*}{$\mathrm{SO}_{4}{ }^{-2}$} & Schist & n.c. & n.c. & - & - & - & + & - & - & - \\
\hline & Granite & n.c. & n.c. & - & - & - & + & - & - & - \\
\hline & Mortar & n.c. & n.c. & - & - & - & + & - & - & - \\
\hline \multirow{3}{*}{$\mathrm{HCO}_{3}{ }^{-}$} & Schist & n.c. & n.c. & - & - & - & n.c & - & - & - \\
\hline & Granite & n.c. & n.c. & - & - & - & n.c & - & - & - \\
\hline & Mortar & n.c. & n.c. & - & - & - & + & - & - & - \\
\hline \multirow{3}{*}{$\mathrm{PO}_{4}^{-3}$} & Schist & n.c. & n.c. & - & - & - & - & n.c. & n.c. & n.c. \\
\hline & Granite & n.c. & n.c. & - & - & - & - & n.c. & n.c. & n.c. \\
\hline & Mortar & n.c. & n.c. & - & - & - & - & n.c. & n.c. & n.c. \\
\hline \multirow{3}{*}{$\mathrm{NH}_{4}^{+}$} & Schist & n.c. & n.c. & - & - & - & n.c. & n.c. & n.c. & n.c. \\
\hline & Granite & n.c. & n.c. & - & - & - & n.c. & n.c. & n.c. & n.c. \\
\hline & Mortar & n.c. & n.c. & - & - & - & n.c. & n.c. & n.c. & n.c. \\
\hline \multirow{3}{*}{ Minerals } & Schist & $+($ d.k.;d.v. $)$ & $+($ d.k.;d.v. $)$ & $+($ d.v. $)$ & - & - & - & - & - & - \\
\hline & Granite & n.c. & n.c. & - & - & - & - & - & - & - \\
\hline & Mortar & - & - & - & - & - & - & n.c. & n.c. & n.c. \\
\hline
\end{tabular}

I: infrared, B: burn, G: glyphosate, S: sulphosate, G-a: glufosinate-ammonium, O: oxyfluorfen, O. v:: Origanum vulgare L., T. z.: Thymus zygis Loefl. ex L., T. v.: Thymus vulgaris L.

Both physical infrared and burning treatments caused notable mineralogical changes in schist, such as the disappearance of kaolinite and vermiculite (Table 5), as indicated in the X-ray diffractograms. The high temperatures (above $800^{\circ} \mathrm{C}$ ) reached in both treatments led to the dehydroxylation of kaolinite and the loss of water from the interlaminar space of the vermiculite.

Regarding the mortars, none of the treatments caused mineral alterations (Table 5). This is probably due to the fact that the mortars are very hardened, with (as indicated in Section 3.1) all the lime $(\mathrm{CaO})$ converted into calcite $\left(\mathrm{CaCO}_{3}\right)$, a thermally highly stable mineral.

Regarding the salt content, we expected an increase in the ammonium salt after treatment with glyphosate and glufosinate-ammonium and an increase in the formation of sulphates after the application of sulphosate; however, none of these changes occurred. Before and after the application of the three chemical treatments, the ion contents were low, and no changes were detected (Table 5). 
After one year, none of the three chemical treatments caused further mineralogical changes. It was also confirmed that the herbicides glyphosate, sulphosate and glufosinateammonium did not induce saline residues on the wall materials.

In the laboratory tests, the colour of the samples varied with the treatments (Table 6). The colour changes were more notable in schist than in granite. In the schist samples, sulphosate caused a perceptible change (with an average value of around 4 CIELAB units) in all three colour parameters. All treatments reddened the schist $\left(\Delta \mathrm{a}^{*}\right)$ and led to a noticeable reduction in the yellow component $\left(\Delta b^{*}\right)$. In granite, perceptible changes were detected in the $b^{*}$ parameter after the application of glyphosate, indicating a perceptible reduction (with an average value around 3 CIELAB units) in the yellow component of the stone colour due to the treatment. Furthermore, granite samples darkened perceptively after the application of sulphosate and glufosinate-ammonium (Table 6).

Table 6. Partial changes in lightness $\left(\Delta \mathrm{L}^{*}\right)$, the green-red colour component $\left(\Delta \mathrm{a}^{*}\right)$ and the blue-yellow colour component $\left(\Delta \mathrm{b}^{*}\right)$, and total colour change $\left(\Delta \mathrm{E}_{\mathrm{ab}}^{*}\right)$. According to the values obtained and taking a threshold of 3 CIELAB units, perceptible changes ( $\geq 3$ CIELAB units) are indicated in bold. n.c.: not considered.

\begin{tabular}{|c|c|c|c|c|c|c|c|c|c|c|}
\hline & & G & S & G-a & $\mathrm{O}(0.5 \%)$ & $\mathrm{O}(1.25 \%)$ & O (100\%) & O. $v$. & T. $z$. & T. $v$. \\
\hline \multirow{2}{*}{$\Delta \mathrm{L}^{*}$} & Schist & $\begin{array}{c}-1.13 \pm \\
0.58\end{array}$ & $\begin{array}{c}-4.03 \pm \\
0.81\end{array}$ & $\begin{array}{c}-2.11 \pm \\
0.35\end{array}$ & $\begin{array}{c}-0.60 \pm \\
0.87\end{array}$ & $+0.17 \pm 1.00$ & $\begin{array}{c}-17.20 \pm \\
5.28\end{array}$ & $\begin{array}{c}-0.96 \pm \\
0.88\end{array}$ & $\begin{array}{c}-0.67 \pm \\
0.34\end{array}$ & $\begin{array}{c}-0.70 \pm \\
0.06\end{array}$ \\
\hline & Granite & $\begin{array}{c}-1.52 \pm \\
0.34\end{array}$ & $\begin{array}{c}-3.55 \pm \\
0.93\end{array}$ & $\begin{array}{c}-3.68 \pm \\
0.74\end{array}$ & n.c. & $\begin{array}{c}-2.86 \pm \\
0.19\end{array}$ & n.c. & $+1.16 \pm 0.58$ & $+4.75 \pm 1.13$ & $+1.50 \pm 0.49$ \\
\hline \multirow{2}{*}{$\Delta \mathrm{a}^{*}$} & Schist & $\begin{array}{c}+4.26 \pm \\
0.63\end{array}$ & $+4.53 \pm 0.82$ & $+4.02 \pm 0.82$ & $\begin{array}{c}-0.02 \pm \\
0.13\end{array}$ & $+0.10 \pm 0.17$ & $+7.68 \pm 2.42$ & $+0.02 \pm 0.08$ & $\begin{array}{c}-0.02 \pm \\
0.07\end{array}$ & $+0.00 \pm 0.12$ \\
\hline & Granite & $\begin{array}{c}-0.94 \pm \\
0.29\end{array}$ & $\begin{array}{c}-0.91 \pm \\
0.45\end{array}$ & $\begin{array}{c}-0.71 \pm \\
0.25\end{array}$ & n.c. & $\begin{array}{c}-0.32 \pm \\
0.87\end{array}$ & n.c. & $\begin{array}{c}-0.63 \pm \\
0.84\end{array}$ & $\begin{array}{c}-1.21 \pm \\
0.43\end{array}$ & $\begin{array}{c}-0.43 \pm \\
0.24\end{array}$ \\
\hline \multirow{2}{*}{$\Delta \mathrm{b}^{*}$} & Schist & $\begin{array}{c}-5.54 \pm \\
0.91\end{array}$ & $\begin{array}{c}-4.90 \pm \\
0.93\end{array}$ & $\begin{array}{c}-4.34 \pm \\
0.86\end{array}$ & $\begin{array}{c}-0.10 \pm \\
0.61\end{array}$ & $+0.52 \pm 0.88$ & $\begin{array}{c}+12.09 \pm \\
5.57\end{array}$ & $+0.12 \pm 0.04$ & $\begin{array}{c}-0.26 \pm \\
0.18\end{array}$ & $\begin{array}{c}-0.48 \pm \\
0.65\end{array}$ \\
\hline & Granite & $\begin{array}{c}-3.22 \pm \\
0.67\end{array}$ & $\begin{array}{c}-1.40 \pm \\
0.33\end{array}$ & $\begin{array}{c}-1.80 \pm \\
0.51\end{array}$ & n.c. & $\begin{array}{c}-0.67 \pm \\
1.70\end{array}$ & n.c. & $+0.97 \pm 0.23$ & $\begin{array}{c}-3.56 \pm \\
0.91\end{array}$ & $\begin{array}{c}-1.24 \pm \\
0.76\end{array}$ \\
\hline \multirow{2}{*}{$\Delta \mathrm{E}_{\mathrm{ab}}^{*}$} & Schist & $7.01 \pm 0.45$ & $7.76 \pm 0.79$ & $6.24 \pm 0.81$ & $0.61 \pm 0.48$ & $0.56 \pm 0.65$ & $22.53 \pm 7.48$ & $0.97 \pm 0.87$ & $0.72 \pm 0.38$ & $0.85 \pm 0.28$ \\
\hline & Granite & $3.64 \pm 0.51$ & $3.87 \pm 0.60$ & $4.08 \pm 0.35$ & n.c. & $3.14 \pm 0.32$ & n.c. & $1.70 \pm 0.84$ & $6.06 \pm 1.51$ & $1.92 \pm 0.75$ \\
\hline
\end{tabular}

G: glyphosate, S: sulphosate, G-a: glufosinate-ammonium, O: oxyfluorfen, O. v.: Origanum vulgare L., T. z.: Thymus zygis Loefl. ex L., T. v.: Thymus vulgaris $\mathrm{L}$.

In the second trial (2016), no mineralogical changes were detected in the construction materials in the wall after the application of oxyfluorfen. Moreover, in general, the amounts of chlorides, nitrates and sulphates increased in the construction materials after the treatment. The first two are produced during the degradation of the herbicide. In addition, the amount of soluble bicarbonates increased in the mortar, probably due to an increase in the $\mathrm{pH}$ provoked by the herbicide.

Regarding the colour change determined in laboratory tests (Table 6), the application of the herbicide at maximum strength $(100 \%)$ produced highly perceptible changes, darkening, reddening and yellowing of the schist samples. Colour changes in $\mathrm{a}^{*}$ were three times higher and changes in $b^{*}$ were six times higher than the threshold of 3 CIELAB units, and changes in $\mathrm{L}^{*}$ exceeded 20 CIELAB units. Thus, total colour changes $\left(\Delta \mathrm{E}_{\mathrm{ab}}^{*}\right)$ of 30 CIELAB units were reached. The application of herbicide at $1.25 \%$ (twice) produced a barely perceptible darkening in the granite and no perceptible colour changes in the schist. No colour change was observed when oxyfluorfen was applied at the lowest concentration $(0.5 \%)$ to schist samples.

Finally, in the third trial (2018), there were no mineralogical changes or changes in the salt content. The only deleterious effect occurred after the application of Thymus zygis Loefl. ex L. essential oil to the granites, which caused a perceptible increase in lightness and a perceptible reduction in the yellow component, of slightly more than 3 CIELAB units, which resulted in a total colour change $\left(\Delta \mathrm{E}_{\mathrm{ab}}^{*}\right)$ of around 6 CIELAB units (Table 6$)$. 


\section{Discussion}

In the last two decades, there has been a major shift in thinking with regard to the herbicidal treatments applied to cultural heritage. The treatments have changed from invasive procedures such as controlled burning and flooding [22] and the use of chemical herbicides containing harmful compounds to the present use of natural, eco-innovative compounds with a low risk to human health, e.g., essential oils and quorum sensing inhibitors [36,37].

The efficacy of herbicides or other protective measures has been tested numerous times against target plants, but as already noted, the question regarding how the treatments affect masonry materials has rarely been examined. In this respect, although herbicides are commonly used to prevent the growth of weeds, very few products have been tested or developed specifically for use on historic masonry materials. Indeed, most products are borrowed from agricultural and landscape applications.

The first published investigation into whether chemical treatments affect masonry is from the late 1970s [25] and the next major study of the effects of a herbicide on historic masonry was carried out 1989 [26]. In the former, brick and mortar samples (clay brick, clay tile, terracotta, cinder block, concrete block, adobe) were soaked in two different herbicides (Roundup ${ }^{\circledR}$ and Garlon ${ }^{\circledR} 4$ ) for one week. In the latter, Roundup ${ }^{\circledR}$, Weed-B-Gon ${ }^{\circledR}$, and borax were applied to brick, limestone, concrete and granite. Both studies concluded that the cumulative use of herbicides could cause mechanical damage and staining on stone and mortars. In a later comprehensive study, in 1999, in which a glyphosate-basedherbicide (Round-up ${ }^{\circledR}$ ) was tested [22], it was concluded that glyphosate causes three types of damage to masonry. It first attacks calcareous stone by acid dissolution. Secondly, the compound and the solvent (in this case water) introduce or redeposit soluble salts. Thirdly, in the presence of calcium, the compound forms insoluble salts. In acid rocks, such as schist, glyphosate also caused mineralogical changes, such as the disappearance of vermiculite, as confirmed in the present study. However, the most important problem with glyphosate is the doubt regarding the danger it poses to human health. According to several studies, the potentially carcinogenic effects of glyphosate are complex in nature [38]. Although considered a probable carcinogen by the IARC since 2015, many regulatory agencies, including the European Food Safety Authority and European Chemicals Agency, continue to hold that glyphosate is unlikely to pose a carcinogenic risk [38].

In Galicia (NW Spain), during the 1990s, chemicals such as Neo Desogen, Paragon Invisible, Hyvar-X, Sanit-S and the cleaning agent AB-57 (a calcium dissolving solvent) were used to remove lichens and algae from granite monuments. The deleterious effects of these compounds are similar to those caused by Goal Supreme ${ }^{\circledR}$ in the present study. Hence, although there was no mineralogical alteration, there was an appreciable colour change, in addition to saline efflorescence after treatment [39]. Important colour changes of more than 30 CIELAB units were reported by Tretiach et al. [24] after the application of biocide (Koretrel@) to grey granite. However, the change in colour was reversible because after washing the sample in running tap water for $48 \mathrm{~h}$, the colour change measured was less than one CIELAB unit. In the present study, the colour change induced can be considered more stable over time, as it was observed up to three months after application.

The use of chemicals will be increasingly questioned in terms of both human safety and environmentally friendliness. However, this attention should also be extended in the field of the conservation of stone monuments and buildings, to determine the short-term and long-term potential damage to historic masonry materials caused by herbicides or other protective measures. Indeed, according to a recent review on natural biocides for the conservation of stone cultural heritage, only 15 of 94 evaluated the interference of the substances with the materials [36]. This additional information can be considered a very important factor in the decision-making process. According to Pinna [40], chlorinecontaining compounds and hydrogen peroxide-based biocides are now avoided in the cultural heritage field because they can interact negatively with stone materials; in addition, oxidizing metal ions (e.g., iron) are strongly oxidizing chemicals that can cause rust or 
black stains, even though they are often stabilized by adding acids. To the best of our knowledge, this type of damage has not yet been observed after the use of essential oils, such as those used in the third trial carried out on the Roman wall of Lugo. Considering the lower toxicity of the essential oils tested in this work, together with the absence of deleterious effects on the building materials in the Roman wall of Lugo, these products may represent a promising alternative to chemical compounds for biodeterioration control, although it cannot be guaranteed that the following application of the same products will not cause a noticeable colour change. The manufacturing cost could also be a major obstacle to the application of these natural compounds (mainly on very large structures such as the Roman wall of Lugo), which may be much more expensive to produce than the conventional treatments currently in main use.

\section{Conclusions}

In this study, trends in the use of herbicides in the last 20 years were examined from the point of view of how the compounds have affected masonry material. Physical (infrared and burning) treatments based on the application of high temperatures (above $800{ }^{\circ} \mathrm{C}$ ) were completely ruled out after a first application in 1998, because they caused irreversible mineralogical alterations in the schist, the main construction material in the Roman wall of Lugo. Among the other treatments, only oxyfluorfen left salt residues, and all treatments caused perceptible colour changes. As the colour of the wall is already heterogeneous owing to differences in the colour of the various materials and pieces of the same material, the perceptible colour changes caused by treatments should not represent a problem regarding conservation of the monument.

Furthermore, considering the restrictions on the use of chemicals in parks and public gardens (where parts of the Roman wall of Lugo occur), herbicidal treatments should focus on environmentally friendly technologies with low risk to human health and should not damage the construction materials. In this respect, Origanum vulgare L. and Thymus vulgaris L. essential oils seem to be most appropriate, as they did not provoke any mineralogical alterations or changes in the salt content and original colour.

Author Contributions: Conceptualization, B.P. and B.S.; methodology, B.P., P.S., J.C.-G., L.T. and B.S.; formal analysis, B.P., P.S., J.C.-G., L.T. and B.S.; investigation, B.P., P.S. and B.S.; writing-original draft preparation, P.S.; writing-review, B.P. and P.S.; supervision, B.P. and B.S. All authors have read and agreed to the published version of the manuscript.

Funding: The results of the different studies presented here were financially supported by the following contracts: "Evaluación de diferentes métodos de control de las malas hierbas de la muralla de Lugo. Xunta de Galicia. Consellería de Cultura, Comunicación Social e Turismo. 1998 and 1999"; "Seguimiento de los tratamientos de control de la flora vascular en la muralla romana de Lugo. Restauraciones y Construcciones Luis J. Sánchez SA. 2015-2017”; “Realizar el seguimiento del segundo tratamiento fitosanitario 2017 y realizar un ensayo de herbicidas naturales en las paredes da muralla. Restauraciones y Construcciones Luis J. Sánchez SA. 2017-2018”; “Realizar el seguimiento de la limpieza manual de las paredes de la muralla romana de Lugo en el verano-otoño de 2019 y la aplicación en las paredes de la muralla romana de Lugo de herbicidas naturales potenciales para controlar la germinación de Parietaria Judaica L. Restauraciones y Construcciones Luis J. Sánchez SA. 2019-2020". The authors are also grateful for financial support from the Xunta de Galicia (grant ED431C 2018/32).

Institutional Review Board Statement: Not applicable.

Informed Consent Statement: Not applicable.

Data Availability Statement: Not applicable.

Acknowledgments: The authors are grateful to Antonio Rigueiro Rodríguez and Elvira Antonia Díaz Vizcaíno, who collaborated in the programming, planning and monitoring of the activities contemplated in the projects listed in the section above.

Conflicts of Interest: The authors declare no conflict of interest. 


\section{References}

1. Faraci, G. Ensuring the Conservative Process: The Roman Walls of Lugo Maintenance Plan. Conserv. Manag. Archaeol. Sites 2016, 18, 411-421. [CrossRef]

2. Prieto, B.; Sanmartín, P.; Pereira-Pardo, L.; Silva, B. Recovery of the traditional colours of painted woodwork in the Historical Centre of Lugo (NW Spain). J. Cult. Herit. 2011, 12, 279-286. [CrossRef]

3. Torres García, L. Flora vascular de la muralla de Lugo: Control del crecimiento y germinación de la dominante Parietaria judaica L. Ph.D. Thesis, Universidade de Santiago de Compostela, Lugo, Spain, 2018.

4. Motti, R.; Bonanomi, G.; Stinca, A. Deteriogenic Flora of the Phlegraean Fields Archaeological Park: Ecological Analysis and Management Guidelines. Nord. J. Bot. 2020, 38, 1-11. [CrossRef]

5. Favero-Longo, S.E.; Viles, H.A. A review of the nature, role and control of lithobionts on stone cultural heritage: Weighing-up and managing biodeterioration and bioprotection. World J. Microbiol. Biotechnol. 2020, 36, 100. [CrossRef]

6. Gaylarde, C. Influence of Environment on Microbial Colonization of Historic Stone Buildings with Emphasis on Cyanobacteria. Heritage 2020, 3, 1469-1482. [CrossRef]

7. Motti, R.; Bonanomi, G. Vascular plant colonisation of four castles in southern Italy: Effects of substrate bioreceptivity, local environment factors and current management. Int. Biodeterior. Biodegrad. 2018, 133, 26-33. [CrossRef]

8. Sanmartín, P.; Miller, A.Z.; Prieto, B.; Viles, H.A. Revisiting and reanalysing the concept of bioreceptivity 25 years on. Sci. Total Environ. 2021, 770, 145314. [CrossRef]

9. Francis, R.A. Wall ecology: A frontier for urban biodiversity and ecological engineering. Progr. Phys. Geogr. 2011, 35, 43-63. [CrossRef]

10. Fisher, G.G. Weed damage to materials and structures. Int. Biodeterior. Bullettin 1972, 8, 101-103.

11. Motti, R.; Bonanomi, G.; Stinca, A. Biodeteriogens at a southern Italian heritage site: Analysis and management of vascular flora on the walls of Villa Rufolo. Int. Biodeterior. Biodegrad. 2021, 162, 105252. [CrossRef]

12. Caneva, G.; Ceschin, S.; De Marco, G. Mapping the risk of damage from tree roots for the conservation of archaeological sites: The case of the Domus Aurea, Rome. Conserv. Manag. Archaeol. Sites 2006, 7, 163-170. [CrossRef]

13. Caneva, G.; Galotta, G.; Cancellieri, L.; Savo, V. Tree roots and damages in the Jewish catacombs of Villa Torlonia (Roma). J. Cult. Herit. 2009, 10, 53-62. [CrossRef]

14. Kanellou, E.; Economou, G.; Papafotiou, M.; Ntoulas, N.; Lyra, D.; Kartsonas, E.; Knezevic, S. Flame weeding at archaeological sites of the Mediterranean region. Weed Technol. 2017, 31, 396-403. [CrossRef]

15. Trotta, G.; Savo, V.; Cicinelli, E.; Carboni, M.; Caneva, G. Colonization and damages of Ailanthus altissima (Mill.) Swingle on archaeological structures: Evidence from the Aurelian Walls in Rome (Italy). Int. Biodeterior. Biodegrad. 2020, 153, 105054. [CrossRef]

16. Mouga, T.; Almeida, M. Neutralisation of herbicides: Effects on wall vegetation. Int. Biodeterior. Biodegrad. 1997, 40, 141-149. [CrossRef]

17. Caneva, G.; Nugari, M.P.; Salvadori, O. Plant Biology for Cultural Heritage: Biodeterioration and Conservation; The Getty Conservation Institute: Los Angeles, CA, USA, 2008.

18. Introduction to Weeds and Herbicides. Available online: https://extension.psu.edu/introduction-to-weeds-and-herbicides (accessed on 29 May 2021).

19. Caneva, G.; De Marco, G. Il Controllo Della Vegetazione Nelle Zone Archeologiche e Monumentali, Atti del Convegno 'Manutenzione e Conservazione del Costruito, fra Tradizione e Innovazione'; Libreria Progetto: Bressanone, Italy, 1986; pp. 553-570.

20. Ceschin, S.; Bartoli, F.; Salerno, G.; Zuccarello, V.; Caneva, G. Natural habitats of typical plants growing on ruins of Roman archaeological sites (Rome, Italy). Plant Biosyst. 2016, 150, 866-875. [CrossRef]

21. Honeyborne, D.B. Weathering and decay of masonry. In Conservation of Building and Decorative Stone; Ashurst, J., Dimes, F.G., Eds.; Butteworth: Guildford, UK, 1990; Volume 1, pp. 153-184.

22. Dewey, C.C. An Investigation into the Effects of an Herbicide on Historic Masonry Materials. Master's Thesis, University of Pennsylvania, Philadelphia, PA, USA, 1999.

23. Altieri, A.; Coladonato, M.; Lonati, G.; Malagodi, M.; Nugari, M.P.; Salvadori, O. Effects of biocidal treatments on some Italian lithotypes samples. In Proceedings of the 4th International Symposium on the Conservation of Monument in the Mediterraneum, Rhodes, Greece, 6-11 May 1997; Moropoulou, A., Zezza, F., Kollias, E., Papachristodoulou, Eds.; Technical Chamber of Greece: Athens, Greece, 1997; Volume 3, pp. 31-40.

24. Tretiach, M.; Crisafulli, P.; Imai, N.; Kashiwadani, H.; Moon, K.; Wada, H.; Salvadori, O. Efficacy of a biocide tested on selected lichens and its effects on their substrata. Int. Biodeterior. Biodegrad. 2007, 59, 44-54. [CrossRef]

25. James, E.F. The Effects of Herbicides on Masonry; National Technical Information Service: Springfield, VA, USA, 1978.

26. Cook, L. The Effects of Herbicides on Masonry: Products, Choices and Testing. Master's Thesis, Columbia University, New York, NY, USA, 1989.

27. Tiano, P.; Caneva, G. Procedures for the elimination of vegetal biodeteriogens from stone monuments. In Proceedings of the ICOM 8th Triennial Meeting, Sydney, Australia, 6-11 September 1987; pp. 1201-1205.

28. Mishra, A.K.; Jain, K.K.; Garg, K.L. Role of higher plants in the deterioration of historic buildings. Sci. Total Environ. 1995, 167, 375-392. [CrossRef] 
29. Prieto, B.; Sanmartín, P.; Silva, B.; Martinez-Verdú, F. Measuring the color of granite rocks. A proposed procedure. Color Res. Appl. 2010, 35, 368-375. [CrossRef]

30. CIE S014-4/E; Colorimetry Part 4: CIE $1976 L^{*} a^{*} b^{*}$ Colour Space; Commission Internationale de L'eclairage, CIE Central: Bureau, Vienna, 2007.

31. UNE-EN 15886; Conservation of Cultural Property—Test Methods—Colour Measurement of Surfaces; Asociación Española de Normalización y Certificación: Madrid, Spain, 2011.

32. Berns, R.S. Billmeyer and Saltzman's Principles of Color Technology, 3rd ed.; Wiley: New York, NY, USA, 2000.

33. Völz, H.G. Industrial Color Testing; Wiley-VCH: Weinheim, Germany, 2001.

34. Sanmartín, P.; Chorro, E.; Vázquez-Nion, D.; Martínez-Verdú, F.M.; Prieto, B. Conversion of a digital camera into a non-contact colorimeter for use in stone cultural heritage: The application case to Spanish granites. Meas. J. Int. Meas. Confed. 2014, 56, 194-202. [CrossRef]

35. Capdevila, R. Le Métamorphisme Régional Progressif et les Granites Dans le Segment Hercynien de Galice Nord Orientale (NW de l'Espagne). Ph.D. Thesis, University of Montpellier, Montpellier, France, 1969.

36. Fidanza, M.R.; Caneva, G. Natural biocides for the conservation of stone cultural heritage: A review. J. Cult. Herit. 2019, 38, 271-286. [CrossRef]

37. Raveau, R.; Fontaine, J.; Lounès-Hadj Sahraoui, A. Essential Oils as Potential Alternative Biocontrol Products against Plant Pathogens and Weeds: A Review. Foods 2020, 9, 365. [CrossRef] [PubMed]

38. Davoren, M.J.; Schiestl, R.H. Glyphosate-based herbicides and cancer risk: A post-IARC decision review of potential mechanisms, policy and avenues of research. Carcinogenesis 2018, 39, 1207-1215. [CrossRef] [PubMed]

39. Prieto, B.; Rivas, T.; Silva, B. The effect of selected biocides on granites colonized by lichens. In Biodeterioration and Biodegradation, 1st ed.; Bousher, A., Chandra, M., Edyvean, I.R., Eds.; Inst. Chemistry: Rugby, UK, 1995; Volume 9, pp. $204-209$.

40. Pinna, D. Coping with Biological Growth on Stone Heritage Objects: Methods, Products, Applications, and Perspectives; Apple Academic Press: Waretown, NJ, USA; CRC Press, Taylor and Francis Group: Boca Raton, FL, USA, 2017. 